\title{
Rhodopseudomonas rutila, a New Species of Nonsulfur Purple Photosynthetic Bacteria
}

\author{
T. AKIBA, ${ }^{*}$ R. USAMI, AND K. HORIKOSHI \\ The Institute of Physical and Chemical Research, Wako, Saitama 351, Japan
}

\begin{abstract}
Strains $\mathrm{R} 1^{\mathrm{T}}$ (type strain) and $\mathrm{R} 2$, two new isolates of nonsulfur purple photosynthetic bacteria, were studied. The cells of these organisms were gramnegative nonsporeforming rods that were motile by means of a single flagellum, and they multiplied by budding. The photosynthetic membrane systems of these strains were of the lamellar type parallel to the cytoplasmic membrane. Cells which formed under anaerobic conditions in the light were red. The cells of these strains contained bacteriochlorophyll $a$, ubiquinone 10, and carotenoids. No vitamins were required as growth factors, and reduced sulfur compounds could not be utilized by strains $\mathrm{R} 1^{\mathrm{T}}$ and $\mathrm{R} 2$. These two strains produced molecular hydrogen anaerobically in the light. On the basis of this study, we propose a new species, Rhodopseudomonas rutila, for strains $\mathrm{R} 1^{\mathrm{T}}$ and $\mathrm{R} 2$. The guanine-pluscytosine contents of the deoxyribonucleic acids of strains $\mathrm{R} 1^{\mathrm{T}}$ and $\mathrm{R} 2$ are 67.6 and $69.4 \mathrm{~mol} \%$, respectively. The type strain of this new species is strain R1 (= ATCC 33872 ).
\end{abstract}

The nonsulfur purple photosynthetic bacteria are able to grow either anaerobically in the light or aerobically in the dark by using various organic compounds as carbon sources and electron donors. These bacteria have been known to have versatile capacities, one of which is to produce molecular hydrogen (3). Recently, the production of molecular hydrogen by photosynthetic bacteria has attracted special attention as a biotechnological means for fuel production $(6$, $8,9,12,19)$.

In attempts to isolate photosynthetic bacteria that are capable of producing molecular hydrogen, we obtained several strains from soil samples. Two of these isolates, strains $\mathrm{R} 1^{\mathrm{T}}$ (type strain) and R2, were studied in the work described below to establish their taxonomic positions.

\section{MATERIALS AND METHODS}

Isolation and medium. Strains $\mathrm{R} 1^{\mathrm{T}}$ and $\mathrm{R} 2$ were isolated from soils from rice fields. The isolation medium contained the following components (per liter): yeast extract (Difco Laboratories), $2.0 \mathrm{~g}$; sodium L-malate, $2.0 \mathrm{~g}$; sodium glutamate, $2.0 \mathrm{~g} ; \mathrm{KH}_{2} \mathrm{PO}_{4}, 1.0$ g; $\mathrm{NaHCO}_{3}, 0.5 \mathrm{~g} ; \mathrm{MgSO}_{4} \cdot 7 \mathrm{H}_{2} \mathrm{O}, 0.2 \mathrm{~g}$; $\mathrm{CaCl}_{2} \cdot 2 \mathrm{H}_{2} \mathrm{O}, 0.1 \mathrm{~g} ; \mathrm{MnSO}_{4} \cdot \mathrm{H}_{2} \mathrm{O}, 2.0 \mathrm{mg}$; $\mathrm{FeSO}_{4} \cdot 7 \mathrm{H}_{2} \mathrm{O}, 0.5 \mathrm{mg}$; $\mathrm{CoCl}_{2} \cdot 6 \mathrm{H}_{2} \mathrm{O}, 0.5 \mathrm{mg}$; thiamine, $1.0 \mathrm{mg}$; nicotinic acid, $1.0 \mathrm{mg}$; and biotin, 0.01 mg. Unless otherwise stated, this medium was used for both aerobic and anaerobic cultures throughout this study.

Isolation medium solidified with $1.5 \%$ agar in deep test tubes was inoculated with soil samples, and the preparations were incubated anaerobically at $30^{\circ} \mathrm{C}$ at a light intensity of about $5,000 \mathrm{~lx}$. After 1 to 2 weeks of incubation, a purplish red color developed in the medium. The strains were subsequently purified three times by streaking onto the agar medium described above.

Characterization of isolates. For morphological and physiological tests, cells were grown aerobically in the dark on isolation agar medium at $30^{\circ} \mathrm{C}$. Standardized procedures $(5,18)$ were used for the following physiological tests: hydrolysis of starch, gelatin, and Tween 80 ; production of hydrogen sulfide from cysteine; reduction of nitrate to nitrite; growth with $3 \% \mathrm{NaCl}$; production of catalase; and temperature and $\mathrm{pH}$ ranges.

The utilization of organic compounds and the utilization of sulfur compounds were tested by growing the strains in a mineral base medium at $30^{\circ} \mathrm{C}$ for 1 week in the light under anaerobic conditions. The medium used contained the following components (per liter): $\mathrm{KH}_{2} \mathrm{PO}_{4}, 1.0 \mathrm{~g} ;\left(\mathrm{NH}_{4}\right)_{2} \mathrm{SO}_{4}, 1.0 \mathrm{~g} ; \mathrm{MgSO}_{4} \cdot 7 \mathrm{H}_{2} \mathrm{O}, 0.2$ g; $\mathrm{NaCl}, 0.1 \mathrm{~g}$; and $\mathrm{CaCl}_{2} \cdot 2 \mathrm{H}_{2} \mathrm{O}, 0.01 \mathrm{~g}$. The organic compounds were added at concentrations of $2.0 \mathrm{~g} / \mathrm{liter}$ unless otherwise indicated and the sulfur compounds were added at concentrations of $0.5 \mathrm{~g} /$ liter. Cell growth was measured with a spectrophotometer at $680 \mathrm{~nm}$. To determine vitamin requirements, thiamine, nicotinic acid, and biotin were tested by using the same medium supplemented with $2.0 \mathrm{~g}$ of L-malate per liter.

Molecular hydrogen was determined by gas chromatography on a molecular sieve $13 \mathrm{X}$ column (60 to 80 mesh; $4 \mathrm{~m}$ by $3 \mathrm{~mm}$ ) that was operated at $50^{\circ} \mathrm{C}$ and was equipped with a thermal conductivity detector. The carrier gas was nitrogen, and the flow rate was 40 $\mathrm{ml} / \mathrm{min}$.

Nitrogenase activity was assayed by acetylene reduction to ethylene as described by Hillmer and Gest (6), using $20 \mathrm{mM} \mathrm{L-malate} \mathrm{instead} \mathrm{of} \mathrm{lactate} \mathrm{as} \mathrm{the}$ substrate. Hydrogenase activity was assayed by measuring the reduction of methylviologen spectrophoto- 


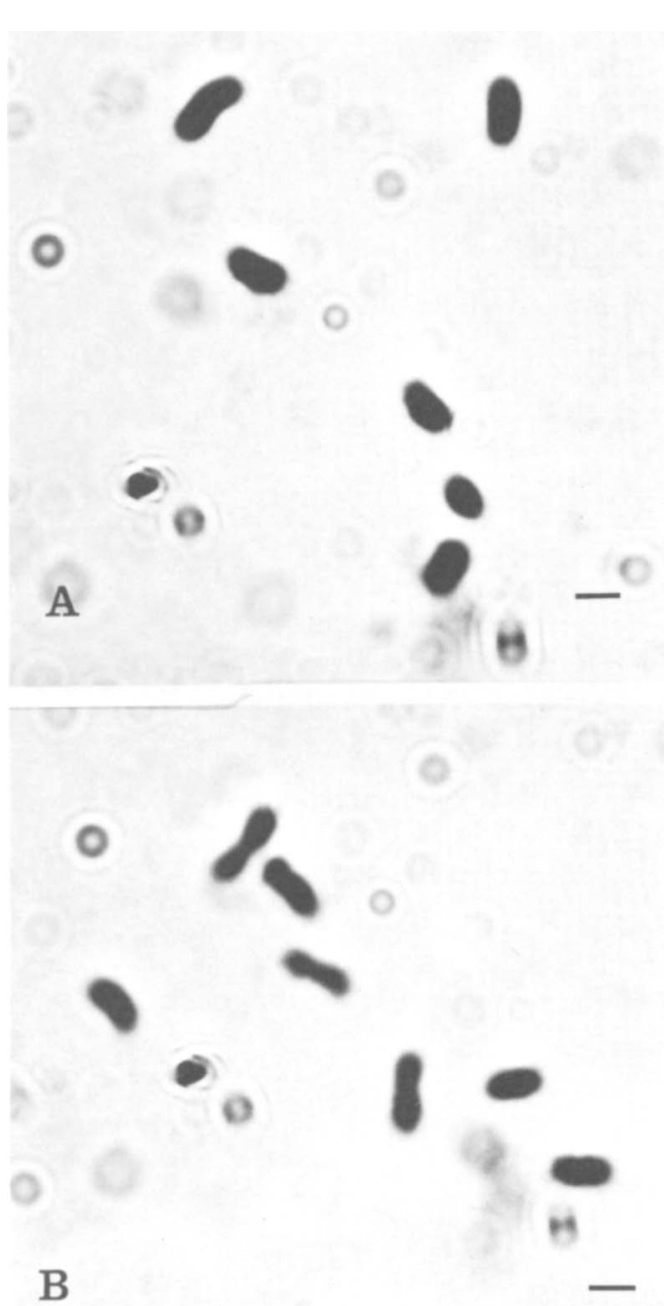

FIG. 1. Phase-contrast photomicrographs of strain $\mathrm{R} 1^{\mathrm{T}}(\mathrm{A})$ and strain $\mathrm{R} 2(\mathrm{~B})$. Bar $=1 \mu \mathrm{m}$.

metrically at $700 \mathrm{~nm}$, as described by Kleiner and Burris (10).

Carotenoids were extracted from cells by the method of Liaaen-Jensen and Jensen (11) and were separated by thin-layer chromatography on silica gel, using benzene-acetone $(93: 7, \mathrm{vol} / \mathrm{vol})$ as the eluant.

Absorption spectra of intact cells and cell-free extracts. Cells grown photosynthetically were harvested by centrifugation, washed twice with distilled water, and suspended in distilled water. Portions of the suspensions were treated for $5 \mathrm{~min}$ with a $10-\mathrm{kc}$ sonic oscillator and then centrifuged to separate cell-free extracts. The absorption spectra of the cell suspensions and cell-free extracts were recorded with a Gilford model 2400-S spectrophotometer.

Identification of ubiquinone. Photosynthetically grown cells were harvested and freeze-dried. The ubiquinones in $0.5 \mathrm{~g}$ of dry cells were extracted three times with $20 \mathrm{ml}$ of isopropyl alcohol. To each extract
$100 \mathrm{ml}$ of $n$-hexane was added to extract the ubiquinones, and the $n$-hexane layer was washed once with $85 \%$ methanol and twice with $95 \%$ methanol. After the $n$-hexane was evaporated, the residue was dissolved in ethanol and then subjected to paper chromatography by the method of Carr and Exell (1).

DNA base composition. The base compositions of the deoxyribonucleic acids (DNAs) of the isolates were determined by the method of Marmur and Doty (13, 14), using a Gilford model $2400-S$ spectrophotometer.

Electron microscopy. Cells grown photosynthetically were fixed in glutaraldehyde and osmium tetroxide, embedded in epoxy resin, cut with a ultramicrotome, and examined with a Hitachi model $\mathrm{H}-300$ electron microscope operated at $75 \mathrm{kV}$.

\section{RESULTS}

Morphological characters. Strains $\mathrm{R} 1^{\mathrm{T}}$ and $\mathrm{R} 2$ had almost identical morphological characteris-
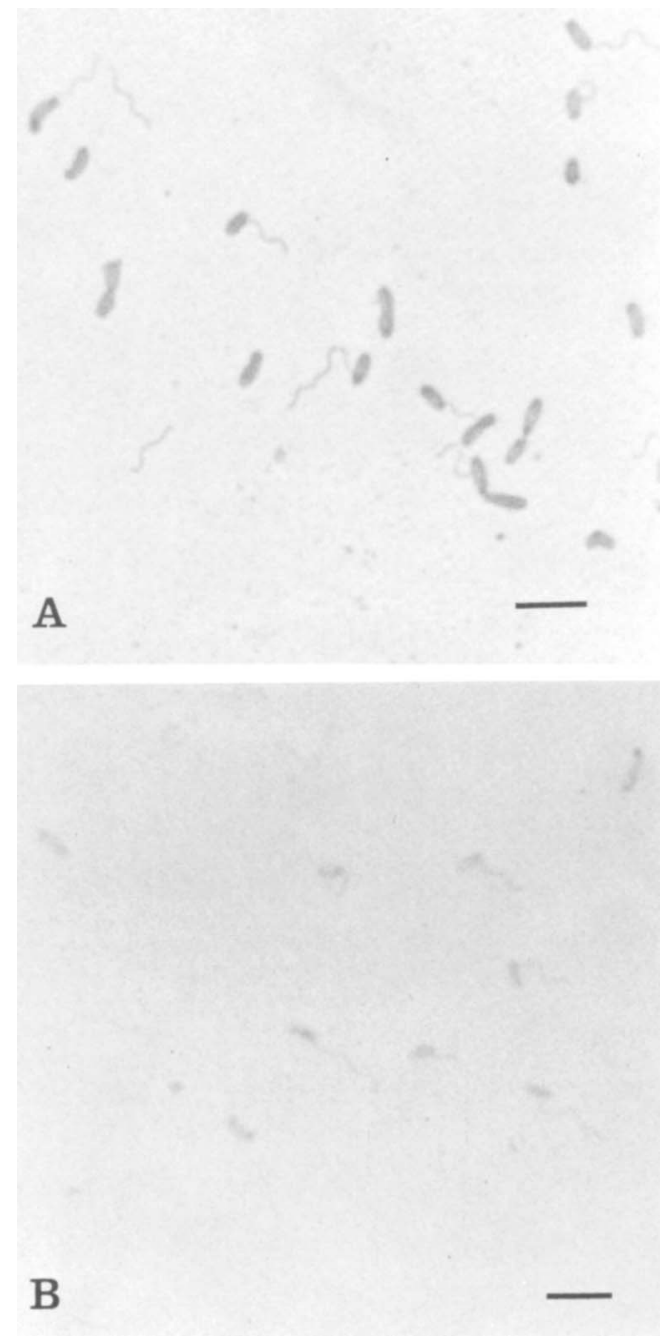

FIG. 2. Flagellum staining of strain $R 1^{\mathrm{T}}$ (A) and strain R2 (B). Bar $=5 \mu \mathrm{m}$. 

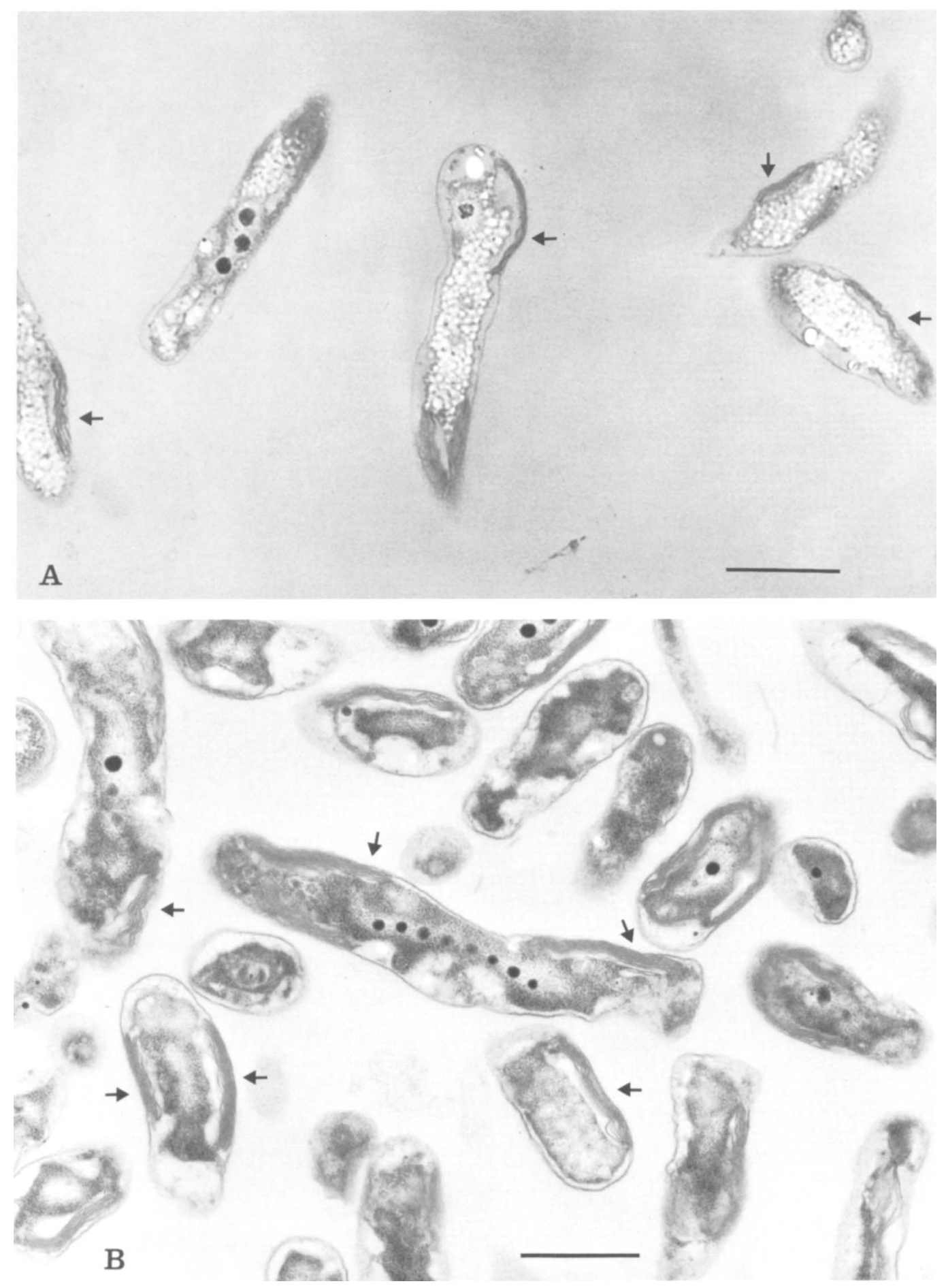

FIG. 3. Ultrathin sections of strain $\mathrm{R} 1^{\mathrm{T}}$ (A) and strain R2 (B) grown photosynthetically, showing lamellar stacks (arrows). Bar $=1 \mu \mathrm{m}$. 


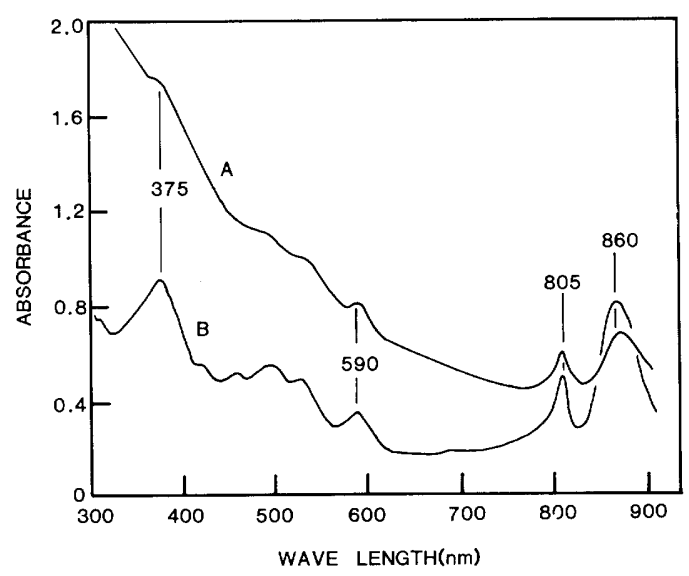

FIG. 4. Absorption spectra of a cell suspension (line A) and a cell-free extract (line $\mathrm{B}$ ) of strain $\mathrm{R} 1^{\mathrm{T}}$.

tics. The cells of these isolates were gramnegative, nonsporeforming rods with rounded ends (Fig. 1) and were motile by means of a single flagellum (Fig. 2). After $12 \mathrm{~h}$ of culture, the cells were 1.5 to $3.0 \mu \mathrm{m}$ long and 0.4 to 1.0 $\mu \mathrm{m}$ wide. Cell multiplication of the two strains occurred by budding, and ultrathin sections of photosynthetically grown cells revealed the presence of lamellar intracytoplasmic membrane systems (Fig. 3). The lamellae formed were extended parallel to the cytoplasmic membrane and in the form of stacks. Both strains were capable of growing either anaerobically in the light or aerobically in the dark. Under anaerobic conditions in the light the cells appeared red. These red cells contained carotenoids and bacteriochlorophyll $a$. The absorption spectra of cell suspensions and cell-free extracts exhibited characteristic maxima at $375,590,805$, and 860 $\mathrm{nm}$, which indicated the presence of bacteriochlorophyll $a$ (Fig. 4). Absorption maxima around 465, 490, and $524 \mathrm{~nm}$ indicated the presence of carotenoids of the spirilloxanthin group. The chromatographic properties and absorption spectra of the carotenoids extracted from the two strains indicated the presence of rhodovibrin and spirilloxanthin. Cells grown aerobically in the dark appeared pale pink to white.

Physiological characteristics. Strains $R 1^{\mathrm{T}}$ and R2 had similar physiological characteristics. Both strains showed negative reactions for the following tests: hydrolysis of starch, gelatin, and Tween 80; production of hydrogen sulfide and hydrogenase; reduction of nitrate; and growth with $3 \% \mathrm{NaCl}$. Both strains produced catalase, nitrogenase, and hydrogen gas. The two strains grew well by using ammonium salts as nitrogen sources but did not grow on nitrates. Neither strain required thiamine, nicotinic acid, or biotin for growth. Vitamin-free Casamino Acids supported growth. However, the addition of thiamine, nicotinic acid, and biotin to the medium stimulated the growth of the two strains. Yeast extract also stimulated the growth of both strains.

Strains $\mathrm{R} 1^{\mathrm{T}}$ and $\mathrm{R} 2$ produced molecular hydrogen under anaerobic conditions in the light by using L-malate, succinate, and lactate as substrates. The cells of both strains contained ubiquinone 10 (coenzyme $\mathrm{Q}_{10}$ ). The $\mathrm{pH}$ ranges for growth of strains $\mathrm{R} 1^{\mathrm{T}}$ and $\mathrm{R} 2$ were between 4.5 and 8.5 , with an optimum $\mathrm{pH}$ of 6.0 to 7.0. The optimum growth temperature was 25 to $30^{\circ} \mathrm{C}$ for strain $\mathrm{R} 1^{\mathrm{T}}$ and 30 to $35^{\circ} \mathrm{C}$ for strain $\mathrm{R} 2$. The maximum growth temperatures for strains $\mathrm{R} 1^{\mathrm{T}}$ and $\mathrm{R} 2$ were 37 and $42^{\circ} \mathrm{C}$, respectively.

Utilization of carbon sources and electron donors. Strains $\mathrm{R} 1^{\mathrm{T}}$ and $\mathrm{R} 2$ utilized several organic compounds as carbon sources and electron do-

TABLE 1. Utilization of carbon sources and electron donors by strains $\mathrm{R} 1^{\mathrm{T}}$ and $\mathrm{R} 2$ and $R$. sphaeroides

\begin{tabular}{|c|c|c|c|}
\hline \multirow[b]{2}{*}{ Substrate } & \multicolumn{3}{|c|}{ Utilization by: } \\
\hline & $\begin{array}{l}\text { Strain } \\
\mathrm{R} 1^{\mathrm{T} a}\end{array}$ & $\begin{array}{c}\text { Strain } \\
\mathbf{R}^{a}{ }^{a}\end{array}$ & R. sphaeroides ${ }^{b}$ \\
\hline Malate & 3 & 3 & + \\
\hline Lactate & 3 & 3 & ND \\
\hline Malonate & 3 & 3 & + \\
\hline Succinate & 3 & 3 & + \\
\hline Caproate $^{c}$ & 2 & 2 & + \\
\hline Glycerol & 2 & 1 & + \\
\hline Glutamate & 1 & 1 & + \\
\hline Fructose & 1 & 1 & + \\
\hline Ethanol & 1 & 1 & + \\
\hline Citrate & 1 & 0 & + \\
\hline Propionate $^{c}$ & 1 & 0 & - \\
\hline Acetate & 0 & 0 & + \\
\hline Formate & 0 & 0 & ND \\
\hline Glucose & 0 & 0 & + \\
\hline Gluconate & 0 & 0 & + \\
\hline Mannitol & 0 & 0 & + \\
\hline Tartrate & 0 & 0 & + \\
\hline Aspartate & 0 & 0 & + \\
\hline Methanol & 0 & 0 & ND \\
\hline Benzoate $^{c}$ & 0 & 0 & ND \\
\hline Caprylate $^{c}$ & 0 & 0 & + \\
\hline Valerate $^{c}$ & 0 & 0 & + \\
\hline Casamino Acids & 3 & 3 & ND \\
\hline Yeast extract & 3 & 3 & + \\
\hline Thiosulfate ${ }^{c}$ & 0 & 0 & - \\
\hline Sulfide ${ }^{c}$ & 0 & 0 & - \\
\hline
\end{tabular}

${ }^{a}$ Expressed as optical densities at $680 \mathrm{~nm}$. 0, Same optical density as a control without added substrate; 1 , optical density of $\leq 0.2 ; 2$, optical density $>0.2$ but $\leq 0.5 ; 3$, optical density of $>0.5$.

${ }^{b}$ Data from Pfennig (15). +, Utilized; -, not utilized; ND, not done.

${ }^{c}$ Tested at a concentration of $0.05 \%$. 
nors (Table 1). Of the organic compounds tested, malate, lactate, succinate, malonate, caproate, glycerol, glutamate, fructose, and ethanol were utilized by both strains. In addition, strain $\mathrm{R} 1^{\mathrm{T}}$ utilized citrate and propionate. No growth occurred on reduced sulfur compounds.

DNA base compositions. The DNA base compositions of strains $\mathrm{R} 1^{\mathrm{T}}$ and $\mathrm{R} 2$ were 67.6 and $69.4 \mathrm{~mol} \%$ guanine plus cytosine, respectively.

\section{DISCUSSION}

The morphologies of the two isolates which we studied were essentially identical. The two isolates were also very similar in their physiological characteristics, except maximum growth temperature, DNA base composition, and utilization of organic compounds. Our results indicate that strains $\mathrm{R} 1^{\mathrm{T}}$ and $\mathrm{R} 2$ belong to the genus Rhodopseudomonas.

There are several species in this genus. In addition to the six species described in Bergey's Manual of Determinative Bacteriology, 8th ed. (17), four new species, Rhodopseudomonas sulfidophila (4), Rhodopseudomonas globiformis (15), Rhodopseudomonas sulfoviridis (7), and Rhodopseudomonas blastica (2), have been reported. Our two isolates differed from these four organisms in the following morphological and physiological characteristics. (i) R. sulfidophila, $R$. globiformis, and $R$. sulfoviridis can utilize sulfide and thiosulfate as electron donors and require vitamins as growth factors, whereas strains $\mathrm{R} 1^{\mathrm{T}}$ and $\mathrm{R} 2$ could not utilize sulfur compounds and did not require vitamins for growth. (ii) $R$. blastica is nonmotile and requires nicotinic acid and thiamine as growth factors; in contrast, strains $\mathrm{R} 1^{\mathrm{T}}$ and $\mathrm{R} 2$ are both motile by means of a single flagellum and do not require these vitamins. (iii) The spectrum of organic compound utilization by strains $\mathrm{R} 1^{\mathrm{T}}$ and $\mathrm{R} 2$ is different from the spectra of the previously described species. In addition, strains $\mathrm{R} 1^{\mathrm{T}}$ and $\mathrm{R} 2$ are able to utilize fewer organic compounds than Rhodopseudomonas sphaeroides (Table 1). The spectrum of organic compound utilization has been one of the criteria for classification in the genus Rhodopseudomonas. The differences described above are considered to be sufficient to place strains $\mathrm{R}^{\mathrm{T}}$ and $\mathrm{R} 2$ in a new species, for which we propose the name Rhodopseudomonas rutila (ru.ti'la. L. adj. rutila red, bloody). The type strain is strain R1 (= ATCC 33872).

The nonsulfur purple photosynthetic bacteria have been classified into three groups according to cell shape and the intracytoplasmic membrane system (16). The organisms of group III, which includes Rhodopseudomonas acidophila, Rhodopseudomonas viridis, Rhodopseudomonas palustris, $R$. sulfoviridis, and $R$. blastica, have rod-shaped to elongated ovoid cells which multiply by budding and develop lamellar and parallel intracytoplasmic membrane systems. Morphologically, the new species $R$, rutila belongs to group III.

Description of Rhodopseudomonas rutila sp. nov. Cells are gram-negative, facultatively aerobic, nonsporeforming rods with rounded ends; cells are 1.5 to $3.0 \mu \mathrm{m}$ long and 0.4 to $1.0 \mu \mathrm{m}$ wide and are motile by means of a single flagellum. Cell multiplication is by budding.

The photosynthetic membrane system is the lamellar type in the form of stacks underlying and parallel to the cytoplasmic membrane.

Both photoorganotrophic growth under anaerobic conditions in the light and chemoorganotrophic growth under aerobic conditions in the dark are possible. Anaerobic cultures are red; aerobic cultures are pale pink to white. No vitamins are required as growth factors. Yeast extract appreciably stimulates growth. The optimum $\mathrm{pH}$ is 6.0 to 7.0 , and the optimum temperature is 25 to $35^{\circ} \mathrm{C}$.

The following organic substrates are photoassimilated: malate lactate, succinate, malonate, caproate, glycerol, propionate, glutamate, fructose, ethanol, and citrate. No growth occurs with acetate, formate, glucose, gluconate, mannitol, tartrate, aspartate, methanol, benzoate, caprylate, or valerate. Sulfide and thiosulfate are not utilized as electron donors.

Starch, gelatin, and Tween 80 are not hydrolyzed.

Hydrogen sulfide is not produced.

Catalase, nitrogenase, and molecular hydrogen are produced, but hydrogenase is not produced.

Nitrates are not reduced.

Ammonium salts and amino acids are utilized as nitrogen sources.

No growth occurs on media containing $3.0 \%$ $\mathrm{NaCl}$.

The cells contain the following photopigments: bacteriochlorophyll $a(375,590,805$, and $860 \mathrm{~nm}$ ) and carotenoids (rhodovibrin and spirilloxanthin). Ubiquinone 10 is present in the cells.

The guanine-plus-cytosine content of the DNA ranges from 67.6 to $69.4 \mathrm{~mol} \%$.

Habitat: mud in rice fields.

Type strain: strain R1 (= ATCC 33872).

\section{ACKNOWLEDGMENTS}

We thank Yung $\mathrm{H}$. Kho, The Korea Advanced Institute of Science and Technology, for cooperation in this study.

This study was supported by a Solar Energy Science Grant from The Institute of Physical and Chemical Research.

\section{LITERATURE CITED}

1. Carr, N. G., and G. Excell. 1965. Ubiquinone concentration in Athiorhodaceae grown under various environmental conditions. Biochem. J. 96:688-692. 
2. Eckersley, K., and C. S. Dow, 1980. Rhodopseudomonas blastica sp. nov.: a member of the Rhodospirillaceae. J. Gen. Microbiol. 119:465-473.

3. Gest, H., and M. D. Kamen. 1949. Studies on the metabolism of photosynthetic bacteria. IV. Photochemical production of molecular hydrogen by growing cultures of photosynthetic bacteria. J. Bacteriol. 58:239-244.

4. Hansen, T. A., and H. Veldkamp. 1973. Rhodopseudomonas sulfidophila, nov. spec., a new species of the purple nonsulfur bacteria. Arch. Mikrobiol. 92:45-58.

5. Harrigan, W. F., and M. E. McCane. 1966. Laboratory methods in microbiology. Academic Press, Inc., London.

6. Hillmer, P., and H. Gest. 1977. $\mathrm{H}_{2}$ metabolism in the photosynthetic bacterium Rhodopseudomonas capsulata: production and utilization of $\mathrm{H}_{2}$ by resting cells. J. Bacteriol. 129:732-739.

7. Keppen, O. I., and V. M. Gorlenko. 1975. A new species of budding purple bacteria containing bacteriochlorophyll b. Mikrobiologiya 44:258-264.

8. Kim, J. S., K. Ito, and H. Takahashi. 1980. The relationship between nitrogenase activity and hydrogen evolution in Rhodopseudomonas palustris. Agric. Biol. Chem. 44:827-833.

9. Kim, J. S., K. Ito, and H. Takahashi. 1981. Production of molecular hydrogen by Rhodopseudomonas sp. J. Ferment. Technol. 59:185-190.

10. Kleiner, D., and R. H. Burris. 1970. The hydrogenase of Clostridium pasteurianum. Kinetic study and the role of molybdenum. Biochim. Biophys. Acta 212:417-427.
11. Liaaen-Jensen, S., and A. Jensen. 1963. Quantitative determination of carotenoids in photosynthetic tissues. Methods Enzymol. 23:586-602.

12. Macler, B. A., R. A. Perloy, and J. A. Bassham. 1979. Hydrogen formation in nearly stoichiometric amount from glucose by a Rhodopseudomonas sphaeroides mutant. J. Bacteriol. 138:446-452.

13. Marmur, J. 1961. A procedure for the isolation of DNA from microorganisms. J. Mol. Biol. 3:208-218.

14. Marmur, J., and P. Doty. 1962. Determination of the base composition of deoxyribonucleic acid from its thermal denaturation temperature. J. Mol. Biol. 5:109-118.

15. Pfennig, N. 1974. Rhodopseudomonas globiformis, sp.n. a new species of the Rhodospirillaceae. Arch. Mikrobiol. 100:197-206.

16. Pfennig, N. 1977. Phototrophic green and purple bacteria: a comparative, systematic survey. Annu. Rev. Microbiol 31:275-290.

17. Pfennig, N., and H. G. Trüper. 1971. Family I. Rhodospirillaceae, p. 26-33. In R. E. Buchanan and N. E. Gibbons (ed.), Bergey's manual of determinative bacteriology, 8th ed. The Williams \& Wilkins Co., Baltimore.

18. Skerman, V. B. D. 1967. A guide to the identification of the genera of bacteria. The Williams \& Wilkins Co. Baltimore.

19. Watanabe, K., J. S. Kim, K. Ito, L. Buranakarl, T. Kampee, and H. Takahashi. 1981. Thermostable nature of hydrogen production by non-sulfur purple photosynthetic bacteria isolated in Thailand. Agric. Biol. Chem. 45:217222 . 